BNL --36312

DE85 012276

THE SPALLATOR - ACCELERATOR BREEDER

M. Steinberg

January 1985

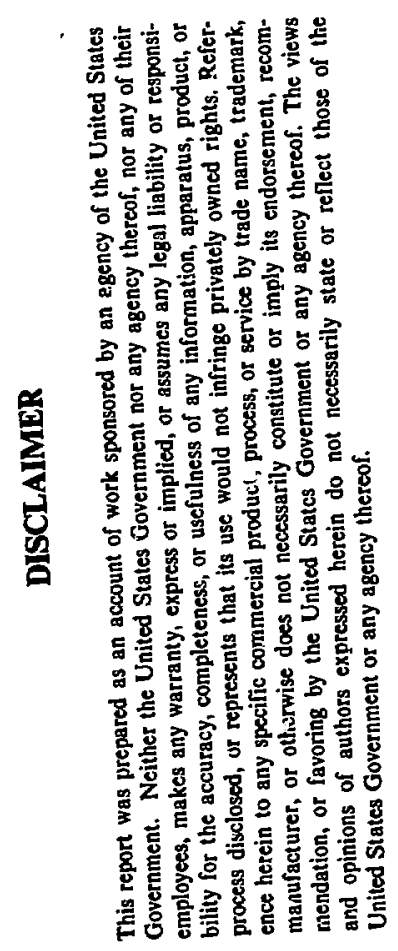

Meyer S teinberg

PROCESS SCIENCES DIVISION

DEPARTMENT OF APPLIED SCIENCE

BROOKHAVEN NATIONAL LABORATORY

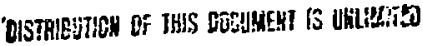

ASSOCIATED UNIVERSTTIES, INC.

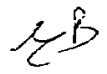

This work was perrormed under the auspices of

J.S. Department of Energy

under contract No. DE-ACO2-76CH00016

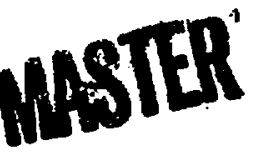


This report was prepared as an account of work sponsored by an agency of the United States Government. Neither the United States Government nor any agency thereof, nor any of their employees, nor any of their contractors, subcontraccors, or their employees, makes any warranty, express or implied, or assumes any legal liability or responsibility for the accuracy, completeness, or usefulness of any information, apparatus, product, or process disclosed, or represents that its use would not infringe privately owned rights. Reference herein to any specific commercial product, process, or service by trade name, trademark, manufacturer, or otherwise, does not necessar1ly constitute or imply its endorsement, recommendation, or favoring by the United States Goverment or any agency, contractor or subcontractor thereof. The views and opinions of authors expressed herein do not necessarily state or reflect those of the Unfted States Government or any agency, contractor or subcontractor thereof. 


\title{
The Spallator - Accelerator Breeder
}

\author{
Departments of Applied Sclence and Nuclear Energy \\ Brookhaven National Laboratory \\ Upton, New York \\ January 1985
}

We have been interested for some time in a concept for breeding nuclear fuel, as an alternative to the LMFBR. The concept involves the wse of spallation neutrons produced by interaction of a high energy proton (1-2 GeV) fron a linear accelerator (LINAC) with a heary metal target (uranium). The spallation neutrons are absorbed in natural fertile material (uranium or thor 1un) to produce f1ssile material (Pu-239 or $\mathrm{V}-233$ ). This machine has been variously called an "accelerator-breeder", an "electric breeder", and a "spallator". Over the years, several spallator concepts have evolved.

The principal spaliator concept is based on generating fissile fuel for use In LWR nuclear power plants, thus assuring a long-term fuel supply for the nuclear industry. The spallator, as we envision the unit, is an energy self-sufficlent machine producing only fissile fuel on demand. As ohown In Figure 1, the spallator functions in conjunction with a reprocessing plant to regenerate and produce the Pu-239 or U-233 for fabrication Into fresh LWR reactor fuel elements.

Advances in proton accelerator technology at Brookhaven and other national iaboratories has provided a solid base for predicting performance and optimizing the design of a reliable, continous wave, high-current LIMAC required by a fisalle fuel production machine. Figure 2 indicates the varlous sections of the LINAC equipment.

Neutron multiplication in the target relies on spallation and fast fission of the heavy elements. Based on earlier experiments at the BNL cosmotron and on high energy Monte Carlo and neutron transport caluclations, the 
neutron yleld and fissile production rate have been deteralned. Evolution of target design at Brookhaven maxilazes fiaslle production rate while relying on near term reactor technology. One reference design, shown in Figure 3, utilizes solid fertile aterial with light water as a coolant in a tight lattice. The target assenbly operates in subcriticel mode. The target is designed to produce enough therwal energy to provide power for the IINAC. One set of reference design paraneters are given in Table 1 . A. single $600 \mathrm{KW}, 300 \mathrm{Ma}-2 \mathrm{GeV}$ proton bean IINAC acting on a uranium spallation target could produce enough fuel to supply nine $1000 \mathrm{MW}(e) \mathrm{LWR}$ power reactors on a continous basis. The estimated economics of the system indicates a competitive position with the LMPBR. The advantage of the spallator is that it can sustain conventional $L G R$ and GCR thermal reactor economies.

To implerent this technology, requires denonstration of the reliability of high-current continous wave accelerator components, accurate measurement of aeutron multiplication in spallation target lattices, and measurement of thermal and hydraulic characteristics of target assemblies.

Small interational programs on spallator technology exist in Canada, Japan, Germany, and the Sorlet Jnlon.

\section{Selected References}

Kouts, H. J. C., and Steinberg, M., "Proceedings of an Information Meeting on Accelerator Breeding," Conf. 77107, held at Brookhaven National Laboratory, Upton, N.Y., sponsored by the U.S. Energy Research and Development Administration, Washington, D.C., (January 18-19; 1977).

Stelnberg M., Grand, P., Takahash1, H., Powell, J. R., and Kouts, H. J. C., "The Spallator - A New Option for Nuclear Power", BNL 33020, Brookhaven National Laboratory, Upton, N.Y., (June 1983).

Steinberg, M., Powell, J. R., and Takahash1, H., "Apex Nuclear Fuel Cycle for Production of Light Water Reactor Fuel and Elimination of Radioactive Waste", Nucl. Technology 1, 58, 437-46 (1982).

Grand, P., Powell, J. R., Stelnberg, M., and Takahash1, H., "Accelezator Breeders, H1ll They Replace Liquid Metal Fast Breeders", BNL 33926, Brookhaven National Laboratory, Epton, N.Y., (June 1983). 


\section{ELECTRICITY}

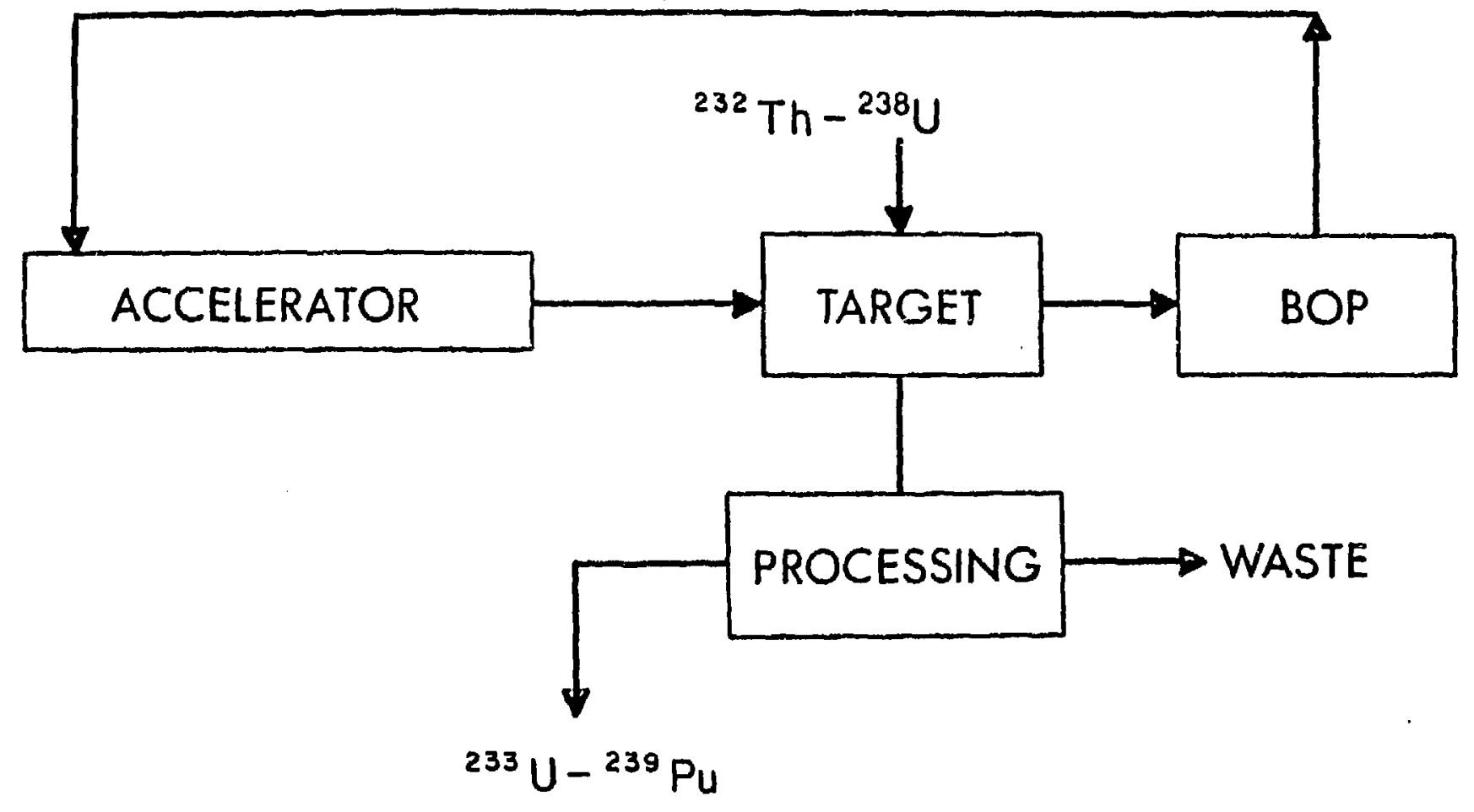

FIGURE 1. ACCELERATOR BREEDER SYSTEM. 


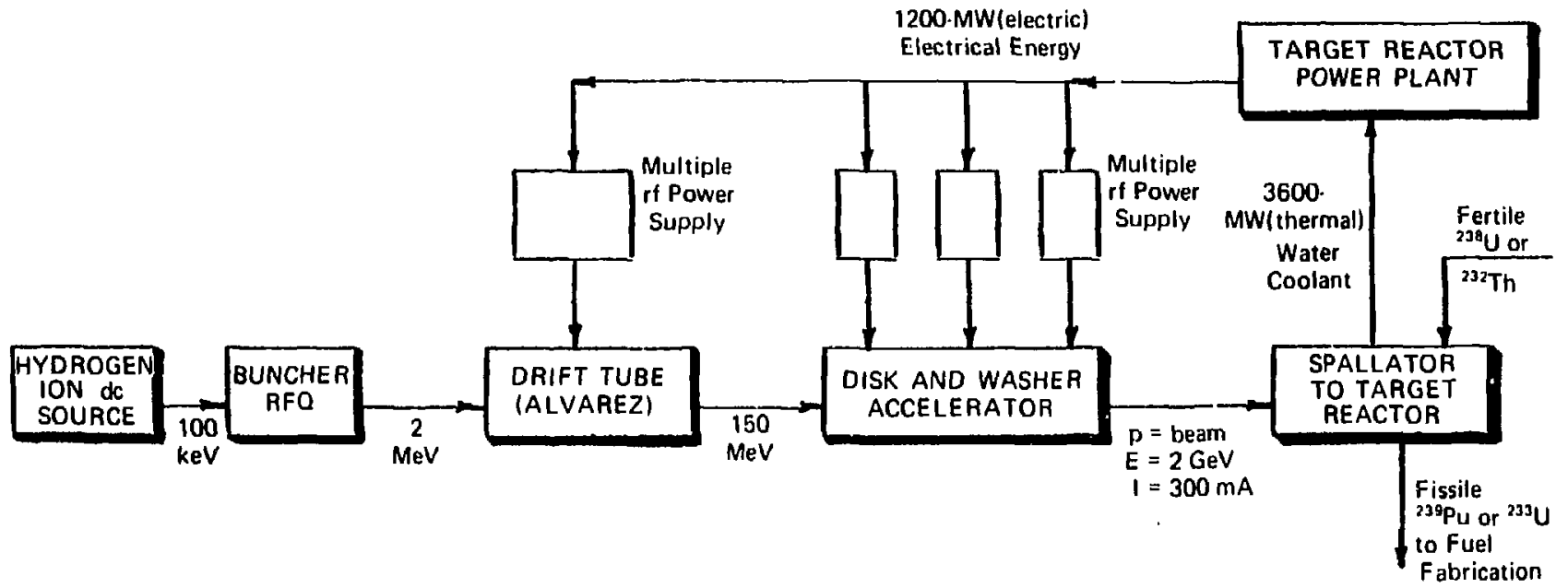

FIGURE 2. THE LINAC FOR THE SPALLATOR. 


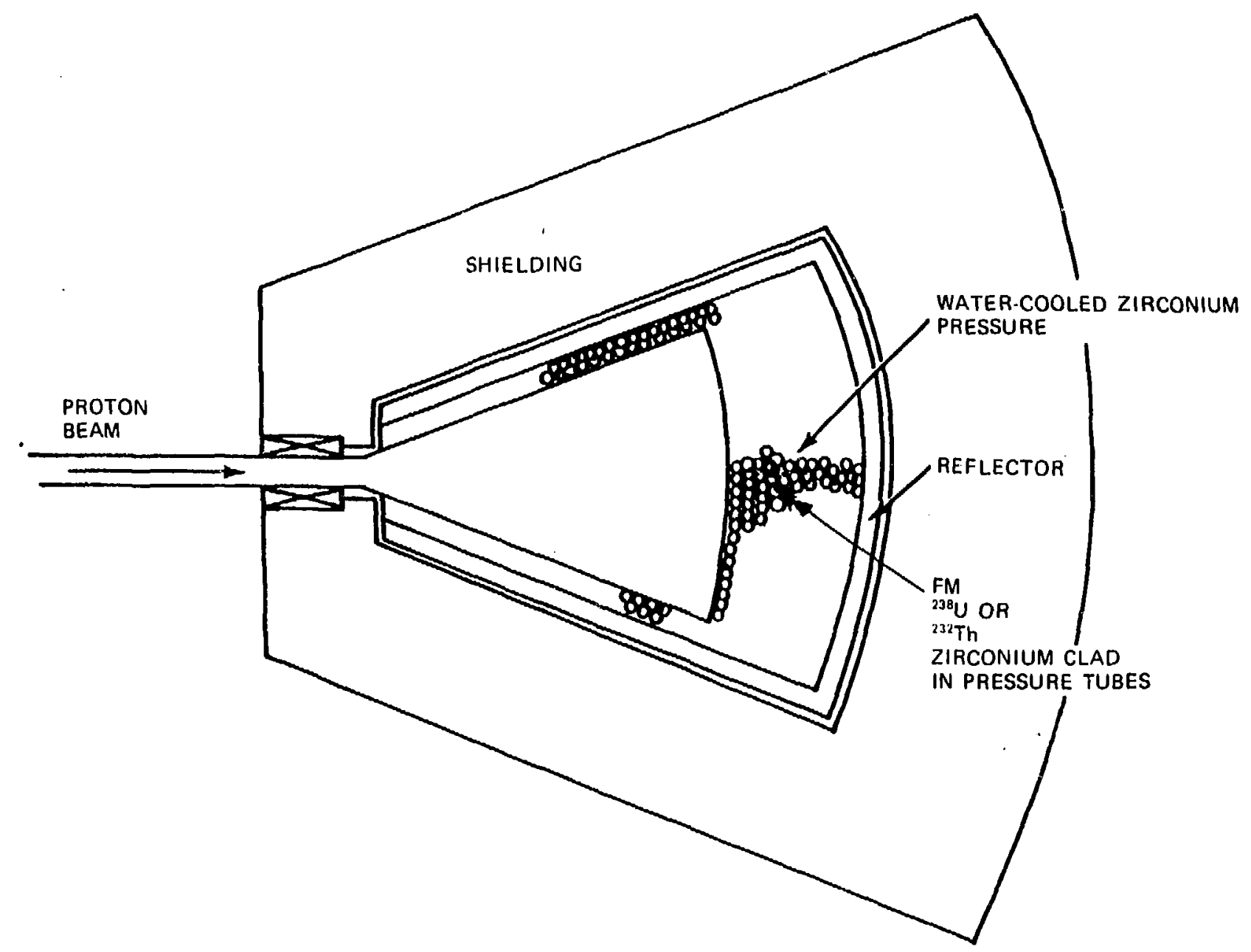

FIGURE 3. THE SPALLATOR T'ARGET DESTGN. 
TABLE I

The Spallator-Accelerator Spallation Reactor-Produclicn Capacity and Design Characteristics

Proton energy

Net fissile atom yield for $\mathrm{UO}_{2} / \mathrm{Zr}$ clad $-\mathrm{H}_{2} \mathrm{O}$ cooled

Current cw

Beam power

Accelerator efficiency

Power to accelerator

Power generated in target

Plant factor

${ }^{239} \mathrm{Pu}$ FF production rate

FF needed for 1 to $1000-M W($ electric) LWR 75\% power factor and 0.6 C.R.

Number of 1000-MW(electric) LWRs supported

\section{$2 \mathrm{GeV}$}

94 fissile atom/GeV/proton

$300 \mathrm{~mA}$

$600 \mathrm{MW}$

$50 \%$

$1200 \mathrm{MW}$ (electric)

$3600 \mathrm{MW}($ thermal) (self-sufficient)

$75 \%$

$3300 \mathrm{~kg} / \mathrm{yr}$

$360 \mathrm{~kg} / \mathrm{yr}$

Nine 